\title{
ハイドロトロピック蒸解における根曲竹成分の樹脂化 $†$
}

(昭 和 35 年 3 月 4 日 受 理)

長谷川 俊勝・伊藤 昌 明*

\begin{abstract}
前報における根曲竹のハイドロトロピック蒸解に続いて，脱ペントザン試料に同様な処理を試みたが，予期に反しリグ ニンの溶出は困難であった。根曲竹の場合にも未晒パルプ中の樹脂分は增加したが，脱ペントザン試料の場合にはより多 量の樹脂分堌加が認められた。

本報告はこの樹脂分生成の由来について究明を行なった。この樹脂分の柴外線扰よび赤外線吸収スペクトルは，リグニ ンと極めて類似している。また可溶化処理の条件によって增減はあるが，樹脂分はメトキシル基を有していることを確認 した。よって根曲竹中のリグニンが可溶化処理中に可溶化液には難溶性で，しかもアルコール・ベンゼン混合溶媒に可溶 性な樹脂状物質に変化するるのと考えられる。

ペントザンは，脱ペントザン試料の場合は問題ではないが，根曲竹を直接処理する際には一部分樹脂化するすのと考兄 られる。セルロースについては樹脂化に特に影響がないと考えられる。
\end{abstract}

\section{1 緒言}

著者らは根曲竹をキシンンスルホン酸ソーダ水溶液が可溶化処 理するときにリグニンはほぼ定量的に溶出することはるちちんで あるが ${ }^{1,2,3)}$ ペントザンも，またその蒸解中にフルフラールに分 解し，その収率が約 50\% であることをキシロースの分解から確 認したことは前報4のと招りである。一方, 未晒パルプの樹脂分 が根曲竹の中のそれよりもふ党る事実を既報可飞述べた。可溶化 処理によってこの様に原試料中の樹脂分よりる多量のそれが生成 するという事実にフルフラールの収率とす関連して興味をるった ので，著者らはこの新たに生成する樹脂分の由来について検索を 行なった。すなわち, 根曲竹からの脱ペントザン試料扮よび根曲 竹の蒸解を行なって, 樹脂分增加汶対するペントザン, セルロー

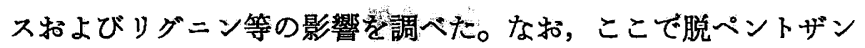
試料を用いたのは根曲竹とそのペントザンを含まない試料との比 較からハイドロトロピック蒸解化括けるペントザン，あるいはフ ルフラールの影響を追求しょうとしたためである。さらに樹脂分 のメトキシル基含量を測定し，溶出リグニンと樹脂分との関係を 追求した。従来, 樹脂分のメトキシル基含量の測定は行なわれて いないが，著者らの測定では興味ある結果が得られた。

\section{2 実 験 方 法}

\section{$2 \cdot 1$ 試料 の性 状}

$2 \cdot 1 \cdot 1$ 脱ペントザン試料 根曲竹を硫酸濃度 $3.5 \%$, 液比 1 : 3. 86，96 $100^{\circ} \mathrm{C}$ とて 5 時間蒸解を行なって得た脱ペントザン試 料を水洗, 乾燥後, Wiley 式粉啸機にて径 $2 \mathrm{~mm}$ 以下の粉末と したるのを試料とした。

\begin{tabular}{|c|c|c|}
\hline \multirow{6}{*}{ 分析値 } & ホロセルロース & $63.8 \%$ \\
\hline & $\alpha$-セルロース & $52.3 \%$ \\
\hline & リグ = ン & $30.5 \%$ \\
\hline & ペントザン & $1.4 \%$ \\
\hline & & $4.6 \%$ \\
\hline & 水 & $8.0 \%$ \\
\hline
\end{tabular}

†本報を「竹および木材のハイドロトロピック溶液による処 理（第 3 報)」とする

* 北海道立工業試娩場 : 札幌市琴似町.

1) H. Lau, Paper Ind. Paper World 23, 247 (1941).

2) R.H. Mc Kee, Ind. Eng. Chem. 38, 382 (1946).

3) 功刀, 内田, 工化 56, 634 (1953).

4) 艮谷川, 伊藤, 工化 62, 1435 (1959).

5）伊藤, 三上，長谷川，工化 61,1100 (1958)
$2 \cdot 1 \cdot 2$ 根曲竹 Wiley 式粉㸴機で径 $2 \mathrm{~mm}$ 以下の粉末とした ものを試料とした。

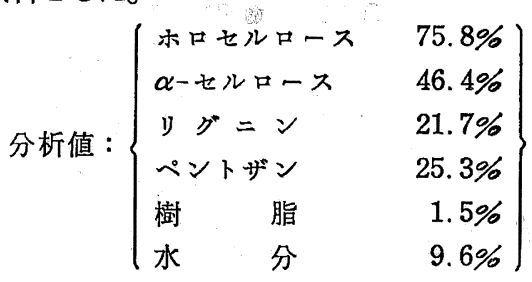

\section{$2 \cdot 2$ 蒸 解 処 理}

試料 $10 \mathrm{~g}$ を小型オートクレーブに入れ，キシンンスルホン酸 ソーダ濃度 $0 \sim 30 \%$ の水溶液（液比 $1: 10$ ) を加克，150 160 ${ }^{\circ} \mathrm{C}$ 飞 2 時間処理を行なった。

\section{3 分 析 方 法}

2.3・1 未唒パルプ 既報らと同様にして求めた。

2·3·1·1 ホロセルロースおよび $\boldsymbol{\alpha}$-セルロース ホロセルロー スについては亜塩素酸法6)を用い， $\alpha$-セルロースについては JIS K 7002 の方法を用いた。

2.3.1.2 樹脂分 未晒パルプ $5 \mathrm{~g}$ をアルコール・ベンゼン (33: 67) を溶媒として, ソックスレー抽出管にて 3〜4 時間抽出 を行なった。抽出液を蒸発皿にらつし，水浴上で溶媒を蒸発し残 留物として樹脂分をえた。な括この重量を原試料（絶乾）飞対す る割合に換算した。

2.3.2 リグニン 既報可々同様にして求めた。

$2 \cdot 4$ リクニンおよび樹脂分の紫外線吸収スペクトル

溶媒にはジオキサンを使用, 試料を $32 \mathrm{mg} / \mathrm{l}$ の濃度に希釈し Beckman DU 型で測定した。

2.5 リグニンおよび樹脂分の赤外線吸収スペクトル 赤外線分光器 : 日立赤外分光光度計 EPI-2 型 プリ ズム: $\mathrm{NaCl}$

試料調整法: $\mathrm{KBr}$ 錠剂法

$2 \cdot 6$ メトキシル基の測定

樹脂分拈よびリグニンのメトキシル基含量をVieböck and Schwappach ${ }^{7}$ の方法を用いて測定した。

\section{3 実験結果および考察}

6) G. Jayme, Cellulose Chemie 43, 20 (1942); L. E. Wise, Ind. Eng. Chem., Anal. Ed. 63, 17 (1945).

7) F. Vieböck, H. Schwappach, Ber. 63, 2818, 3207 (1930); F. E. Brauns, "The Chemistry of Lignin" p, 744 (1952) Açademịc Preșș Inc., New York, 
根曲竹括よび脱ペントザン試料のハイドロトロピック蒸解で得 られた未晒パルプの収率を図 1 亿示した。根曲竹については既 報らの結果とほとんど一致しているが，脱ペントザン試料からの 末晒パルプの収率は根曲竹の場合に比較して高い值を示してい る。また図 2 に示したとうり，脱ペントザン試料の方がリグニン 溶出量は小である。もっともこのリグニン溶出量は可溶化液の濃 度に比例することはるちろんである。

未晒パルプ中の樹脂分と可溶化液の濃度との関係は図 3 K示し た。根曲竹の場合については既報の結果と同様に可溶化液濃度 10\%の場合に最大量を示している。ペントザンを殆ど含まない脱 ペントザン試料の場合にも同様に多量の樹脂が生成し, 溶化液濃 度 $10 \%$ の溶液で処理した際に生成する樹脂量は最大値を示した。

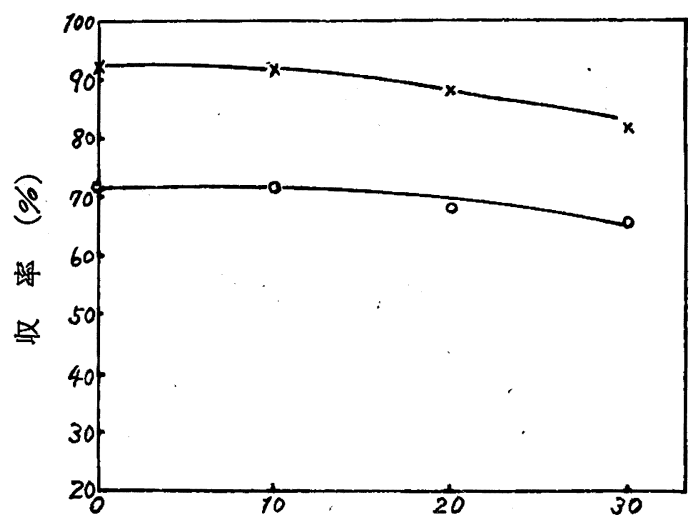

キシレンスルホン酸ソーダ濃度 $(\%)$

因 1 末晒パルプの収率 一○一 根曲竹 $-\times$ 脱ペントザン式料

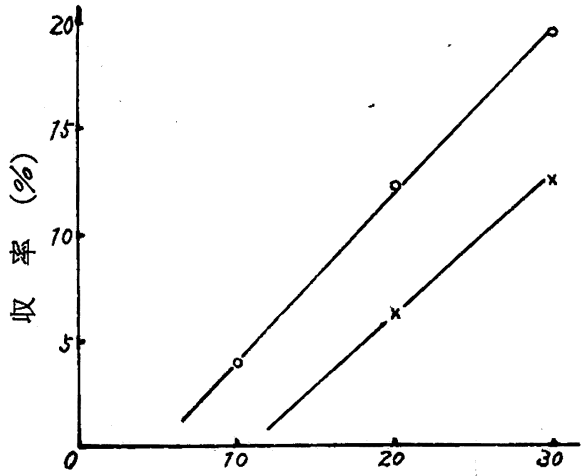

キシレンスルホン酸ソーダ濃度（\%)

図 2 リグニンの収察 一○一 根曲竹 $-\times$ 凩兑ペントザン武料

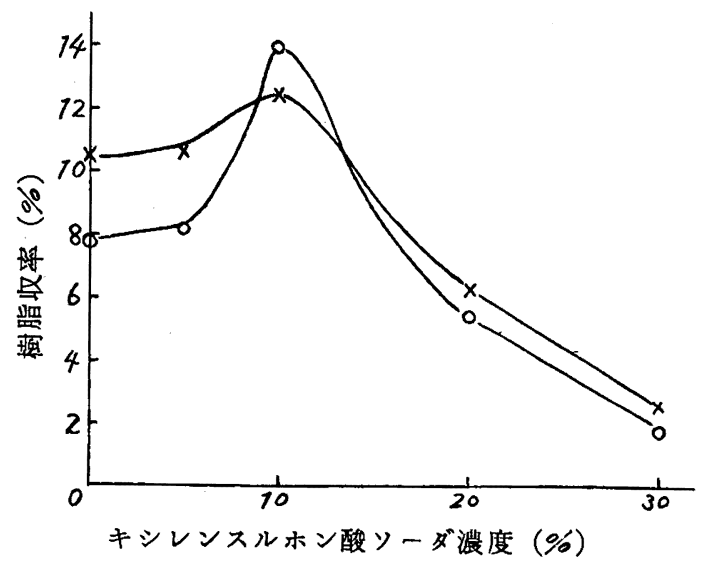

図 3 樹脂 の収 率

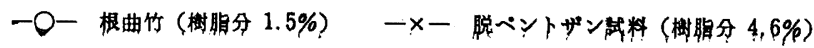

そこで著者らはこの生成樹脂の由来を追求するため，まずこの 蒸解に拈けるホロセルロースおよび $\boldsymbol{\alpha}$ 一セルースの収率を求め, その影響を調べた。その結果を図 4 に示した。

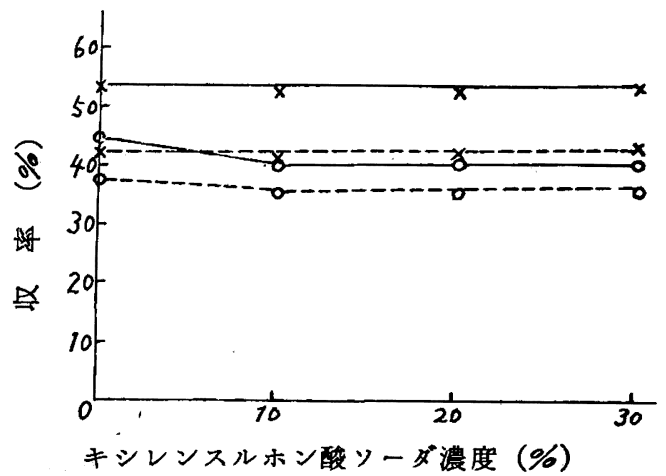

図 4 ホロセルロース拈よび $\alpha$-セルロースの収率 一○一 根曲竹 根曲竹 : ホロセルロース $75.8 \%, \alpha$, 穴ルロース $46.4 \%$

哾ペントザン武料：ホロセルロース $63.8 \%$ ， のーセルロース $52.3 \%$

図 4 に括いて，脱ペントザン試料を各種濃度の可溶化液で処理 した時には，ホロセルロース扰よび $\boldsymbol{\alpha}$ 一セルロースは処理前の值 よりるそれ宅れ約 $10 \%$ 減少している。脱ペントザン試料の場合， ペントザンは僅かであるから，その約 $10 \%$ 減少したホロセルロ 一スに相当するのはセルロースの低重合度部分であり，また $\alpha-$ セルロースが同様に減少していることから蒸解中に $\alpha$-セルロー スの分解あるいは解重合が起っていると考えられる。根曲竹の場 合, 原試料中のホロセルロースは $75.8 \%$ であるが蒸解中にペン トザンが可溶化液中に溶解してゆく5)。原試料中のペントザンの 含量は約 $25 \%$ であるがホロセルロースの収率は約 $35 \%$ 減少し

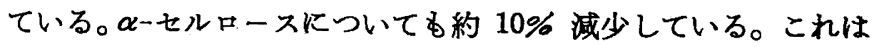
根曲竹の場合にも同様な分解あるいは解重合が㧊こっている事を 示するのである。しかるにこれらの現象は可溶化液による処理に 限った事ではなく可溶化液濃度 0\%すなわち，水のみで同様に処 理しても同様の結果をえた。また伊藤ら息の研究による木材粉の 水处理あるいは著者らの研究(6よるとペントザンは完全には溶 解しないで未晒パルプ中に若干残留する。従ってホロセルロース および $\alpha$-セルロースの減少についてはそれら自身の分解あるい は解重合によると考壳られ，かつ溶化液濃度にほとんど関俰がな い。ここでセルロースの可溶化液中に溶解してゆく部分について 樹脂化の影響を調べるために精製リンターを用いたが，リンター を同様に可溶化処理しても樹脂の生成はほとんどみられなかっ た。よってセルロースの溶解分については樹脂化の影響はほとん どないものと考えられる。

図 3 K括いて，生成した樹脂量は根曲竹の場合す脱ペントザン 試料の場合も同様に $10 \%$ 溶化処理のところで最大值を示してい るむのの, 樹脂量の曲線が平行せず, 根曲竹の方が極めて大なる 值を示し，曲線が交錯していることは根曲竹から生成する樹脂に はペントザンの影響があるからと考えられる。

しかるにペントザンを含まない脱ペントザン試料の蒸解の場合 でも樹脂が生成している。よって樹脂分の生成にはリグニンが大 きく影響するすのと考光さるをえない。従来，木村を井蒸解する ときに木材中の有機酸などによって一部の榶類やリグニンの) 等が

8) 伊藤, 中山，木材学会誌 4, 142 (1958).

9) E. E. Harris, et al, Ind. Eng. Chem., Anal, Ed, 9, 234 (1937); 11, 153 (1939). 
変質したり，変質しないで溶解してくることがわかっている。ま た溶剤可溶の物質（天然の樹脂）中，一部はリグニンであると推 定 ${ }^{10)}$ さている。

著者らは新た《生成した樹脂およびハイドロトロピック・リグ ニンがジオキサンに溶解する事実を見出したので紫外線吸収スペ クトルを測定し，両者の関係を検討した。その結果を図 5 に示す。

図 5 に抹いて，根曲竹と脱ペントザン試料を同濃度の溶化液で 処理して生成した樹脂の紫外線吸収スペクトルは，その吸収量に おいて差が認められるが，非常に類似したものが得られ，またり グニンのそれにす類似している。さらに，根曲竹と脱ペントザン 試料から得られた樹脂のスペクトルを比較した場合，前者ではぺ ントザンあるいはフルフラールからの生成物の影響が加っている はずである。しかしながら，それらのスペクトルが類似している
ことから，ペントザンあるいはフルフラールは溶化液中でリグニ ン類似物質に変化し未晒パルプ中に樹脂分として含まれてくるも のと考光られる。このことについては多くの研究 ${ }^{11)}$ があり, ペン トザンめるいはフルフラールを鉱酸の存在下で加熱するとき，リ グニン類似物質が得られることからも理解できる。

一般に，リグニンの紫外線吸収スペクトルはその波長が 200 $\mathrm{m} \mu$ に近づく従って吸光度は無限大となるのがしられている。 しかるに，この研究ではジオキサンを溶媒とした場合 $\lambda_{\max }=247$ $\mathrm{m} \mu$ で吸収のピークが得られた。これについては図 6 からわかる ように, ジオキサンの溶媒効果である。

また樹脂の赤外線吸収スペクトルの測定を行なったが，リグニ ンのそれと類似のスペクトルを与えた。これは竹リグニンについ て祖父江ら ${ }^{12)}$ の行なった測定結果とほとんど一致するるのであっ て，ただ波数 $1660 \mathrm{~cm}^{-1}$ の吸収は 1700 $\mathrm{cm}^{-1}$ にずれている。また $870 \mathrm{~cm}^{-1}$ の弱 い吸収は $910 \mathrm{~cm}^{-1}$ にずれている。1660 $\mathrm{cm}^{-1}$ の吸収に関しては Jone $\mathrm{e}^{13)}$ はリグニ ンをメタノール・HCl で処理すると，この 吸収が消失することからアルデヒドまたは ケトン基であると推定した。 $870 \mathrm{~cm}^{-1}$ につ いては Bellamy らの研究14によると, ベ ンゼン環の One free hydrogen atom に よるものであるともいわれている。かよう に祖父江らの赤外線吸収スペクトル測定の 結果とほとんど一致することからも, 本研 究に拉ける樹脂括よびリグニンは類似の物 質であるといいうる。

次にリグニン分子中の特性基の 5 ち最も 重要視されているメトキシル基含量の測定 を樹脂拉よびリグニンについて行ない， ハ イドロトロピック蒸解に括けるメトキシル 基含量の変化の関係を求め, メトキシル基 に関してもそれらの間に類似性のあること を確かめた。図 7 からかるように樹脂の メトキシル基含量は使用した溶化液濃度に より影響をうけ，逆比例的な関係で漸次减 少する。すなわち, 高濃度の溶化液で処理 したときには低濃度の場合より樹脂中のメ トキシル基含量は少くなっている。これに

10) H. Hibbert, J. B. Phillips, Can. J. Research 1, 4 (1931).

11) A.P. Dunlop, Ind. Eng. Chem. 40, 204(1948); Samberger, HönigFestschr 109 (1923); W. Eller, Ann. 431, 133, 162, 177 (1923); R. S. Hilpert, S. Wisslinck, Ber. 69, 680 (1936); F. A. H. Rice, A. R. Johnson, J. Org. Chem. 23, 1966 (1958).

12) 祖父江, 福原, 工化 61,1070 (1958).

13) E. J. Jones, Tappi 32, 167 (1949); J. Am. Chem. Soc. 1984 (1948).

14) L. J. Bellamy, The Infra-red Spectra of Complex Molecules 55 (1954). 


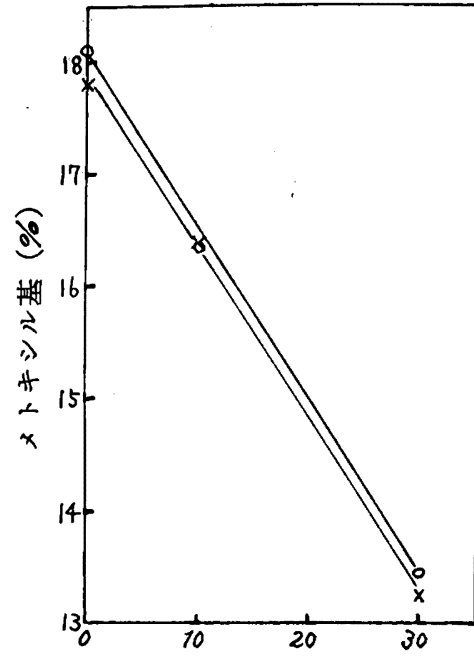

図 7 樹脂のメトキシル基 含量

一Oー 根的竹から得られた樹脂

ーメー 娧ペントザン陚料から得 られた楜脂

メトキシル基含量 :

リグニン $16.3 \%$

末処理根曲竹樹脂 $10.6 \%$, 末处理脱ヘンントザン試料薣 脂 $15.5 \%$

キシレンスルホン酸ソーダ濃度(\%)

ついては脱メトキシル基の現象も一応考えられる。しかし溶出リ グニンのメトキシル基含量が約 16\% と非常に高い值を示し, 樹 脂分のそれは低い値を示している。従ってメトキシル基含量の少
ない部分は溶化液に溶解しがたいということである。なお，メト キシル基含量については根曲竹怙よび脱ペントザン試料から得ら れた樹脂の間では差異が認められない。

ここで最後に溶化液について若千考察すると, キシレンスルホ ン酸ソーダ (溶化液) の濃度をむすことによって，いわゆるハイ ドロトロピーなる効果を現わすのであって，図３において樹脂の 生成が $10 \%$ 溶化処理でピークを示したのは，溶化液はリグニン を変質させ うる能力をるっているが，溶化液の濃度をますに従っ て樹脂分が溶解してゆくためと考えられる。また我処理の場合で も樹脂が生成するのは文献にもあるよ5に，水のみであっても若 干リグニンを変質させらる力があるためである。またメトキシル 基含量の多い部分が樹脂中にあっても溶化液濃度のうすい場合に は，溶出させうる力が少ないためと考えられる。

終りに試料の一部を御惠与いたたいた北海パルプエ業株式会社 および赤外線吸収スペクトルの測定に御援助をいたたいた北大工 学部応用化学教室の御厚意飞謝意を表する。また本研究に終始御 指導をいただき，発表を許可された北海道立工業試験場長 緑川 林造博士に感謝する。

\title{
酢 酸セルロ一スの塩類効果
}

（昭 和 35 年 2 月 12 日 受 理）

林 一未

\begin{abstract}
二, 三の有機溶剤についてその中に塩を溶存する場合と溶存しない場合の酢酸セルロースの極限粘度および濃厚溶液粘 度の比較と，塩化要鉛を主体とする塩類混合水溶液中に拈ける酢酸セルロースの举動に関する既往の知識とから，塩類効 果に関する Rogovin, Lohmann 执よび Malm らの説を批判し，次のような機構を提案した。酢酸セルロースの有機溶 剤分散系に塩が加わると溶剤中の水をらばって水和し，その一部が陽イオンの種類によって定まる形式で酢酸セルロース 分子に吸着せられる。溶剤の含水率が減少するとその溶媒和力が低隇するから，分子鎖間の相互作用が増加するが，一方 塩を吸着した抛点も吸着状態および水和量の多寡に応じた相互作用を生じ，以上二つの相互作用が合成せられて系全体の 粘度の帰䞶が決まる。
\end{abstract}

\section{1 緒言}

酢酸セルロースのある種の有機溶剂分散系（たとえばアセトン 溶液）にある種の塩（たとえば塩化カルシウム）を微量に存在さ せると溶液粘度が異常に増加する現象があり，塩類効果とよばれ ている。この現象が三酢酸セルロースには見られず，もっぱら部 分ケン化物にのみ見られること，1価の陽イオンを有する塩には 見られず，主として 2 価の陽イオンの塩について抗こる事, 瞃酸 セルロース中にカルボキシルまたは結合硫酸を多く含むものによ く見られること等を根拠として, 酢酸セルロースの水酸基, カル ボキシル基または硫酸基等の位置で分子の巨大化がおこるものと 考えられていた。すなわち Rogovin 1) は水酸基の位置で, $\mathrm{Malm}^{2}$ らは硫酸基またはカルボキシル基の位置でそれぞれカルシウム橋 をつくり, Lohmanns) は酿酸セルロースの水酸基の位置で共存

* 帝国人綟（株）研究所：岩国市今津.

1) Z. A. Rogovin, H. Schlyakhover, Kolloid-Z. 78, 224 (1937)

2) C. J. Malm, L. J. Tanghe, G. D. Smith, Ind. Eng. Chem. 42, 730 (1950).

3) H. Lohmann, J.prakt. Chem. 155, 299 (1940),
塩と錯化合物をつくり，隣接分子鎖中の対応部分との間の結合の ために粘度増加がおこるというのである。

われわれは二，三の有機溶剤と塩類との組合わせにおいて三酢 酸セルロースおよび部分ケン化酢酸セルロースの希薄溶液ならび に濃厚溶液の粘度挙動をしらべたが，塩類効果のおこるためには 酢酸セルロース中の水酸基, カルボキシル基, 硫酸基等は機構的 に無関係であることが明らかになったので，上述の諸説に疑問が もたれるに至った。そこで塩化亜鉛を主体とする塩類混合水溶液 中に拈ける酢酸セルロースの挙動に関するわれわれの既往の知識 にもとついて, 次のような塩類効果機構を提案した。

酢酸セルロースの有機溶剂（たとえばアセトン，酢酸等）分散 系に塩が加わると溶剤中の水をらばって水和し，その一部が陽イ オンの種類によって定まる形式で酢酸セルロース分子に吸着され る。その際溶剤中の含水率が減少して溶媒和力が低減するから分 子鎖間の相互作用が增加するが: 一方，塩を吸着した拠点も吸着 状態执よび水和量の多寡に応じた相互作用を生じ，以上二つの相 互作用が合成されて系全体の粘度の帰而が決まる。

以下実験の詳細を述べ，それに立脚した塩類効果機構を検討し よう。 